\title{
Antitumor efficacy of the Egyptian Scorpion Venom Androctonus Australis: in vitro and in vivo study
}

Mohamed S. Nafie ${ }^{1 *}$ D, Mohamed M. Abdel Daim², Ibrahim A. I. Ali ${ }^{1}$, Zohour I. Nabil ${ }^{3}$, Mohamed A. Tantawy ${ }^{4}$ and Mohamed A. Abdel-Rahman ${ }^{3^{*}}$ (D)

\begin{abstract}
Background: Scorpion venom contains various biomolecules with potential therapeutic values against different diseases, including cancer. The present study was carried out to assess the antitumor efficacy of Androctonus australis crude venom using both in vitro and in vivo approaches.

Methodology: For in vitro assay, the cytotoxic effect of different venom concentrations was determined against HCT116, HepG2, MCF-7, and PC-3 as cancer cell lines and normal WISH cell line. The in vivo assay was carried out by the I.P. transplantation of EAC into Swiss albino female mice, followed by the I.P. injection of the venom at the sublethal dose $1 / 10 \mathrm{LD}_{50}(0.025 \mathrm{mg} / \mathrm{kg} \mathrm{BW}$ ) compared to cisplatin $(2 \mathrm{mg} / \mathrm{kg} \mathrm{BW})$, and both normal and EAC control groups were also included. The analysis of ascetic fluid tumor, survival study, and hematological, biochemical, antioxidant, and histopathological assays was evaluated in control and treated animal groups.

Results: Our in vitro results revealed that the A. australis venom had a selective promising activity against MCF-7 cells $\left(I_{50}=19.71 \mu \mathrm{g} / \mathrm{mL}\right)$. Moreover, it was less cytotoxic on WISH cells. The in vivo data showed that $A$. australis venom exhibited a highly significant decrease in tumor volume, and viable tumor cell count, and increased the duration of lifespan compared to the EAC control group. The venom significantly enhanced both hematological and biochemical measurements compared to the EAC control group.

Conclusion: The results revealed that the A. australis venom exhibited in vitro and in vivo antitumor activities. Further venomics studies are needed to functionally characterize the active molecules from this scorpion venom and study their mode of action on cancer cells to develop them into potential anticancer agents.
\end{abstract}

Keywords: A. australis venom, Antioxidant, Cancer, In vitro, In vivo

\section{Introduction}

According to the WHO agency and international cancer agencies, cancer is considered as the second most lethal disease in humans (about 9.6 million cancer deaths in 2018 (Bray et al. 2018)). Liver, colon, breast, stomach,

\footnotetext{
* Correspondence: Mohamed_nafie@science.suez.edu.eg;

mohamed_hassanain@science.suez.edu.eg

${ }^{1}$ Chemistry Department, Faculty of Science, Suez Canal University, Ismailia

41522, Egypt

${ }^{3}$ Zoology Department, Faculty of Science, Suez Canal University, Ismailia

41522, Egypt

Full list of author information is available at the end of the article
}

and lung cancer are considered to be the highest causes of cancer mortality (BW and CP 2014). Classical chemotherapeutic and radio-therapeutic agents are extremely highly cytotoxic with deleterious effect on normal tissues (Ferlay et al. 2015). So, there is an urgent need to employ new strategies for cancer prevention and treatment, such as natural products derived from animal venoms.

Venoms are a rich source of various pharmacologically active molecules (Abdel-Rahman et al. 2015; Harrison et al. 2016) which are being used for treating numerous diseases including cancer (Ghosh et al. 2019). Many venom peptides/proteins revealed remarkable effects 
(anti-proliferative, cytotoxic, apoptogenic, and immunosuppressive) on various types of cancer cell lines (Ejaz et al. 2018; Sarfo-Poku et al. 2016; Ortiz et al. 2015). The characterized scorpion venom proteins or peptides kill cancer cells through different pathways: (i) specifically bind to cell membranes and affecting the proliferation and migration of these cells, (ii) bind to ion channels which affect cancer cell physiology (such as chlorotoxin isolated from the scorpion venom of $L$. quinquestriatus), (iii) exerting antiproliferative or apoptotic activities by induction of caspase-dependent apoptotic pathways or cell cycle arrest (Heinen and Gorini da Veiga 2011; Ding et al. 2014).

Recently, scorpion venoms obtained from various scorpion species (L. quinquestriatus, A. crassicauda, and $A$. amouroxi) revealed potential anticancer effects using in vitro (MDA-MB-231, HCT-8, and MCF-7) and in vivo approaches. The venoms induced cytotoxicity, elevated the reactive oxygen species, and also enhanced apoptotic pathways in these cancer cell lines (Salem et al. 2016; Al-Asmari et al. 2018). Also, from the scorpion of A. australis (one of the most common species in North Africa), the venom fraction F3 induced apoptosis in human lung cancer cell line (NCI-H358) via generation of reactive oxygen and nitrogen species resulted in mitochondrial malfunction (Béchohra et al. 2016). Hence, the current study was conducted to evaluate the anticancer efficacy of $A$. australis venom against various cancer cell lines (in vitro study) and against Ehrlich ascites carcinoma bearing mice (in vivo study).

\section{Material and methods}

\section{Collection of scorpions and venom preparation}

Adult scorpions $(n=150)$ were collected from NorthWestern Egypt (around the Western Mediterranean Coastal Desert), Marsa Matrouh Governorate. Scorpions were kept alive in separate plastic containers to avoid cannibalism. They were fed fortnightly with cockroaches and received water ad labitum. The venom was obtained from scorpions using electrical stimulation $(12-18 \mathrm{~V}, 3$ $\mathrm{ms})$. The milked venom was freeze-dried and stored in Eppendorf tubes at $-20{ }^{\circ} \mathrm{C}$ until use (Abdel-Rahman et al. 2013).

\section{Cell lines and in vitro assay}

Cytotoxicity of scorpion venom was evaluated on different cell lines including colon cancer (HCT116), liver cancer (HepG2), breast Michigan Cancer Foundation-7 (MCF-7), prostate cancer (PC-3), and normal human amniotic epithelial cells (WISH), which were purchased from the National Cancer Center, Egypt. Each cell line (passage no. 16) was propagated in a complete medium composed of RPMI-1640 (Lonza Verviers SPRL, Belgium) supplemented with $10 \%$ fetal bovine serum (Seralab, UK) and 1\% antibiotic (antibiotic antimycotic, Biowest). The cells were incubated in $5 \% \mathrm{CO}_{2}$ humidified at $37^{\circ} \mathrm{C}$ for growth according to the standard tissue culture techniques. After cell culturing, cells were treated with $0.01,0.1,1,10$, and $100 \mu \mathrm{g} / \mathrm{mL}$, and cell survival was determined using Sulpho Rhodamine-B (SRB, Biotium, USA) method (Skehan et al. 1990). $I_{50}$ values were calculated using the sigmoidal concentration-response curve fitting model using GraphPad Prism-7 software.

\section{In vivo assay \\ Implantation of Ehrlich ascites carcinoma cells}

The Ehrlich ascites carcinoma cells (EAC) were purchased from the National Cancer Institute (Cairo University, Egypt). The tumor cell line was propagated in mice through serial intraperitoneal (I.P.) transplantation of a volume of $0.2 \mathrm{~mL}$ physiological saline contains $1 \times 10^{6}$ viable cells for $24 \mathrm{~h}$. EAC cells were collected 7 days after I.P. implantation. The harvested cells were diluted with saline to obtain a concentration of $5 \times 10^{6}$ viable EAC cells/ $\mathrm{mL}$. A volume of $0.2 \mathrm{~mL}$ saline contains $1 \times 10^{6} \mathrm{EAC}$ cells that were I.P. implanted into each normal mouse (El-Azab et al. 2011).

Seventy Swiss Webster female albino mice (20-25g) were housed in plastic cages, under conditions of controlled humidity $\left(22 \pm 2{ }^{\circ} \mathrm{C}\right)$, with free access to standard laboratory mice chow and water. All procedures related to care and maintenance of the animals were performed according to the international guiding principles for animal research and approved by the Suez Canal University bioethics and animal ethics committee (the approval no. 201505). The experimental animals were randomly divided into four groups. Group 1 served as the normal saline control $(5 \mathrm{~mL} / \mathrm{kg}$ BW, I.P.). Group 2 served as the EAC control $\left(1 \times 10^{6}\right.$ cells/mouse, I.P.). Group 3 served as the scorpion venom-treated group $(0.025 \mathrm{mg} / \mathrm{kg} \mathrm{BW}$ which is $1 / 10 \mathrm{LD}_{50}$; Nafie et al. 2014). This low dose $(1 / 10$ $\mathrm{LD}_{50}$ ) was chosen according to our previous biochemical study which revealed less toxicity for this dose on experimental animals (Nafie et al. 2014). Group 4 received the standard anticancer drug of cisplatin $(2 \mathrm{mg} / \mathrm{kg}$ BW, I.P.) and is considered as a reference control. Body weight and survival were recorded daily until the 18th day in both treated and control groups. After 18 days, the blood of each group was collected under light anesthesia for estimation of hematological and biochemical assays. The anesthetized animals were then sacrificed for tissue antioxidant assays, histopathological examination, and evaluation of the antitumor activity.

\section{Anticancer activity of $A$. australis venom}

Potential anticancer effect of $A$. australis venom was evaluated by measuring tumor volume, packed cell volume (PCV \%), tumor cell count, the percentage of tumor 
cell growth inhibition, and cell viability using Trypan blue exclusion assay. The ascitic fluid was collected from the peritoneal cavity, and its volume was measured with a graduated cylinder. PCV of ascetic fluid was estimated using hematocrit capillary tubes (1000 rpm for $5 \mathrm{~min}$ ). Tumor cell count of the diluted ascitic fluid (1:100 0.9\% saline) was manually determined using hemocytometer Neubauer's counting chamber. Percentage of tumor cell growth inhibition (CGI \%) was carried out using the following equation: CGI\% $=1$ - (tumor cell count of treated/ tumor cell count in control) $\times 100$ (Sur and Ganguly 1994). Trypan blue exclusion assay of cell viability was conducted through mixing $10 \mu \mathrm{L}$ of the diluted cell suspension with Trypan blue solution (1:1) (Lazarus et al. 1966). Percentage of increased body weight (IBW \%) was calculated according to the following formula described by Bhatnagar, Pant, Shukla, Panda, and Gupta (2016): IBW\% $=$ (wt. of each animal at the 18th day - wt. of the animal at 0th day) $\times 100$.

\section{Survival study}

The effect of $A$. australis venom on tumor growth was daily monitored by recording the mortality during the period of the experiment for doing the survival study by measuring the mean survival time (MST), the percentage of MST ratio (T/C \%), and percentage of increased life span (ILS \%). The MST for each group was calculated according to the following formula (MST $=\Sigma$ survival days of each mouse/total number of mice) described by (Agrawal et al. 2011a). The percentage of MST ratio (T/C $\%$ ) was calculated using the formula (T/C \% $=$ MST of treated group/MST of control $\times 100$ ) described by Badr et al. (2011). ILS \% was calculated according to the following formula: ILS $\%=($ MST of treated group/MST of control -1$) \times 100$ (Pandya et al. 2013).

\section{Hematological, biochemical, and histopathological assays}

Complete blood count (CBC) was estimated using Abbott CELL-DYN ${ }^{\circ} 1800$ automated hematology analyzer (USA) with ready-made kits (Abbott Laboratories, Abbott Park, IL, USA). The levels of glucose (Triner et al. 1970), cholesterol (Richmond 1973), creatinine (Larsen 1972), and urea (Coulombe and Favreau 1963) were measured in serum using commercial kits (Instrumentation Laboratory SpA, Inova diagnostics, Milano, Italy). Antioxidant assays were evaluated in liver tissue homogenate prepared in phosphate buffer (state the buffer and its concentration). The level of reduced glutathione (GSH; (Beutler et al. 1963)) and the activity of both catalase (CAT; (Aebi 1984)) and superoxide dismutase (SOD; (Nishikimi et al. 1972)) were measured using standard commercial kits (Bio-diagnostic, Cairo, Egypt). For microscopic histopathological examination, pieces of the peritoneal membrane and kidney were kept in $10 \%$ formalin, dehydrated in graded alcohol, embedded in paraffin section, and stained with E\&H stains hematoxylin (Banchroft and Stevens 1996).

\section{Statistical analysis}

Data were statistically analyzed using SPSS software (Statistical Package for Social Science, version 21 for windows) (Nie et al. 1975) and expressed as mean \pm standard error. Unpaired $t$ test was used to find out if there is a significant difference between every two groups. One-way ANOVA followed by the post hoc Duncan test was carried out to find if there was any significant difference between control and treated groups $(P \leq 0.05)$.

\section{Results}

\section{In vitro cytotoxicity of $A$. australis venom}

The cytotoxic effects of different concentrations of $A$. australis venom $(0.01,0.1,1,10$, and $100 \mu \mathrm{g} / \mathrm{mL})$ on human cancer cell lines (MCF-7, HepG2, PC-3, and HCT116) and normal WISH cells were assessed (Table 1). Interestingly the venom showed a promising selective cytotoxic effect against MCF-7 cell line $\left(\mathrm{IC}_{50}=19.71 \mu \mathrm{g} / \mathrm{mL}\right)$, with no detectable cytotoxicity against other cancer and normal cell lines.

\section{In vivo anticancer activity of $A$. australis venom on EAC- bearing mice}

Efficacy of scorpion venom on the ascetic peritoneal fluid of EAC-bearing mice

The effects of $A$. australis venom and cisplatin treatment on the ascetic peritoneal fluid of EAC-bearing mice are represented in Fig. 1. The best parameters for gauging the effectiveness of any anticancer agents are the reduction of tumor volume, packed cell volume (PCV), and viable and total tumor cell count of EAC bearing mice. Treatment with the venom induced a significant $(P \leq 0.05)$ decrease in ascetic fluid tumor volume, PCV, total tumor cell count, and percentage of viable tumor cells by $61.80 \%$, $98.93 \%, 32.88 \%$, and $87.62 \%$, respectively, with a significant increase in the percentage of non-viable tumor cells by $203.75 \%$. Moreover, it induced a significant increase in the percentage of cell growth inhibition (CGI \%), while cisplatin treatment induced a significant decrease in ascetic fluid tumor volume, PCV, total tumor cell count, and percentage of viable tumor cells by $50.73 \%, 63.32 \%$, $34.87 \%$, and $57.11 \%$, respectively, with a significant increase in non-viable tumor cells by $469.89 \%$ compared to the EAC control.

Effect of A. australis venom treatment on survival and body weight of EAC-bearing mice

The treatment of EAC-bearing mice with A. australis venom was found to be more potent against the EACinduced tumor cell growth, which was indicated by the 
Table $1 I C_{50}$ values of $A$. australis venom against different cancer and normal cell lines

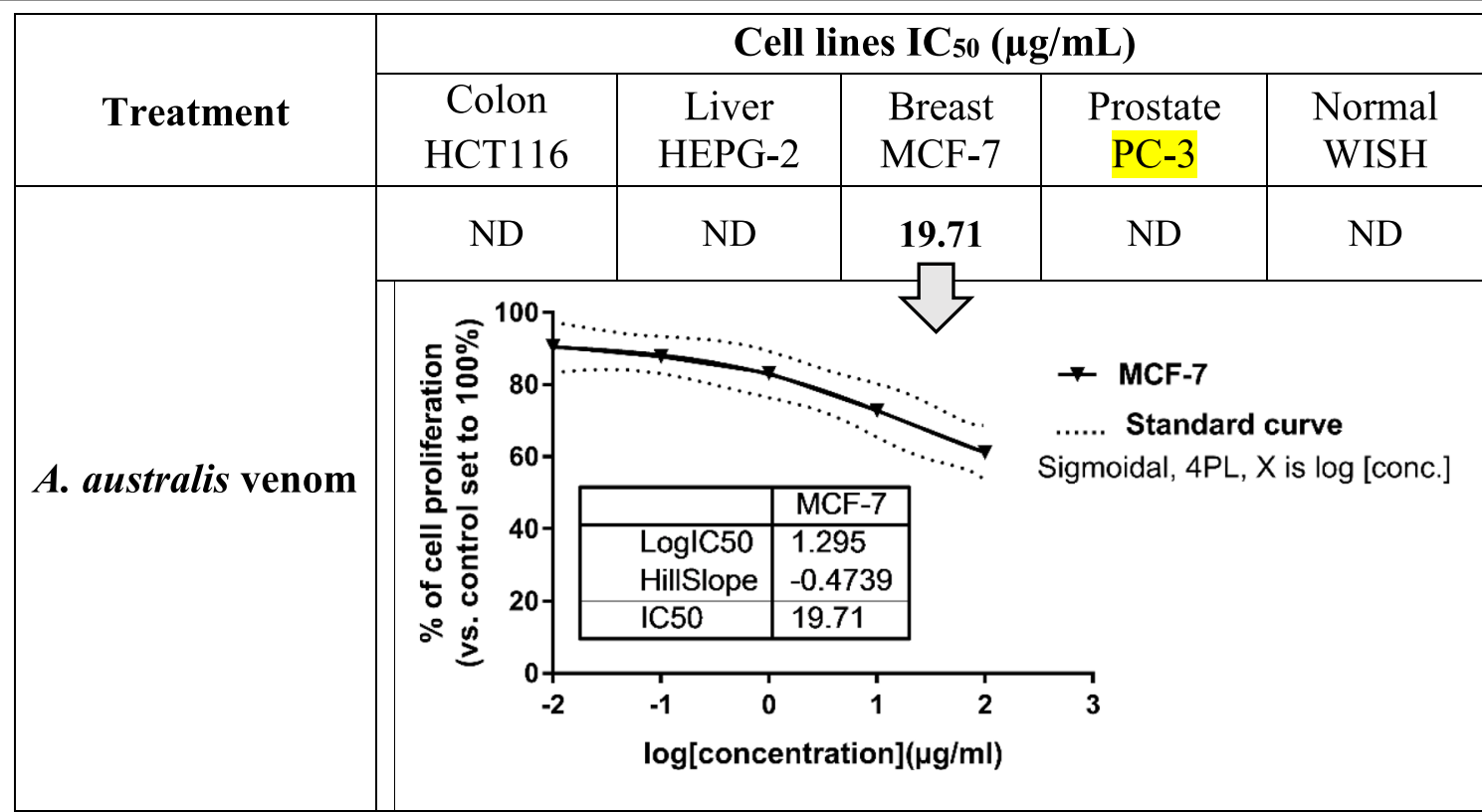

ND: Not Determined

increase in mean survival time from 15.25 to 16.8 days, as well as increase in the percentage of lifespan from 0 to $10.16 \%$ and decrease in the percentage of increased body weight from 29.28 to $18.10 \%$. Mice treated with known standard drug cisplatin showed the maximum increase in mean survival time 17.9 days, increase in lifespan to be $17.38 \%$, and the least percentage of increased body weight $22.03 \%$ as shown in Fig. 2.

\section{Effect of A. australis venom treatment on hematological parameters of EAC-bearing mice}

The effects of $A$. australis venom and cisplatin treatment on hematological parameters of EAC-bearing mice are shown in Table 2. In EAC-bearing mice, all the CBC parameters except granulocytes, monocytes, and platelets counts were found to be significantly changed as compared to those of the normal mice. Treatment with the venom induced a significant increase in hemoglobin content by $133.66 \%$, a significant increase in $\mathrm{RBC}$ count by $124.51 \%$, a significant increase in WBC count by $158.26 \%$ [a non-significant increase in granulocytes and monocyte's counts with a significant increase in lymphocytes by $177.39 \%$ ], and a significant increase in platelet's count by $210.42 \%$, while cisplatin treatment induced a non-significant decrease in hemoglobin content, a nonsignificant increase in RBC count, a significant increase in WBC count by $175.63 \%$ [a significant increase in granulocytes and lymphocytes by $200 \%$ and $200.76 \%$, respectively, with a non-significant increase in monocytes], and a significant increase in platelet count by $235 \%$ compared to the EAC control.
Effect of A. australis venom treatment on biochemical and antioxidant parameters of EAC-bearing mice

The effects of $A$. australis venom and cisplatin treatments on both biochemical and antioxidant parameters of the EAC-bearing mice are summarized in Table 3. Regarding, the biochemical assays. In EAC-bearing mice, all biochemical parameters were found to be significantly increased as compared to normal mice. Treatment with the venom, similar to cisplatin, induced a significant decrease in urea, glucose, and cholesterol, while it caused a non-significant decrease in the creatinine level. Regarding the antioxidant parameters, in EAC-bearing mice, antioxidants (CAT, SOD, and GSH) were non-significantly decreased as compared to normal mice. Treatment with the venom induced a non-significant increase in CAT, SOD, and GSH levels, while cisplatin treatment induced a significant increase in SOD levels $362.48 \%$, a non-significant increase in CAT and GSH levels compared to EAC control.

\section{Histopathological results}

The histopathological changes of peritoneal and kidney tissues in untreated and treated EAC-bearing mice compared to that of normal control mice are shown in Figs. 3 and 4 . It was noticed that the normal control peritoneal membrane is formed of a single layer of flattened mesothelial cells (Fig. 3a), while the EAC control peritoneal membrane was replaced by the proliferation of multiple layers of pleomorphic large cancer cells (Fig. 3b). Venomtreated EAC bearing mice showed improvement in the form of decreased cancer cell proliferation compared to EAC, but scattered cancer cells are still present (Fig. 3c). 


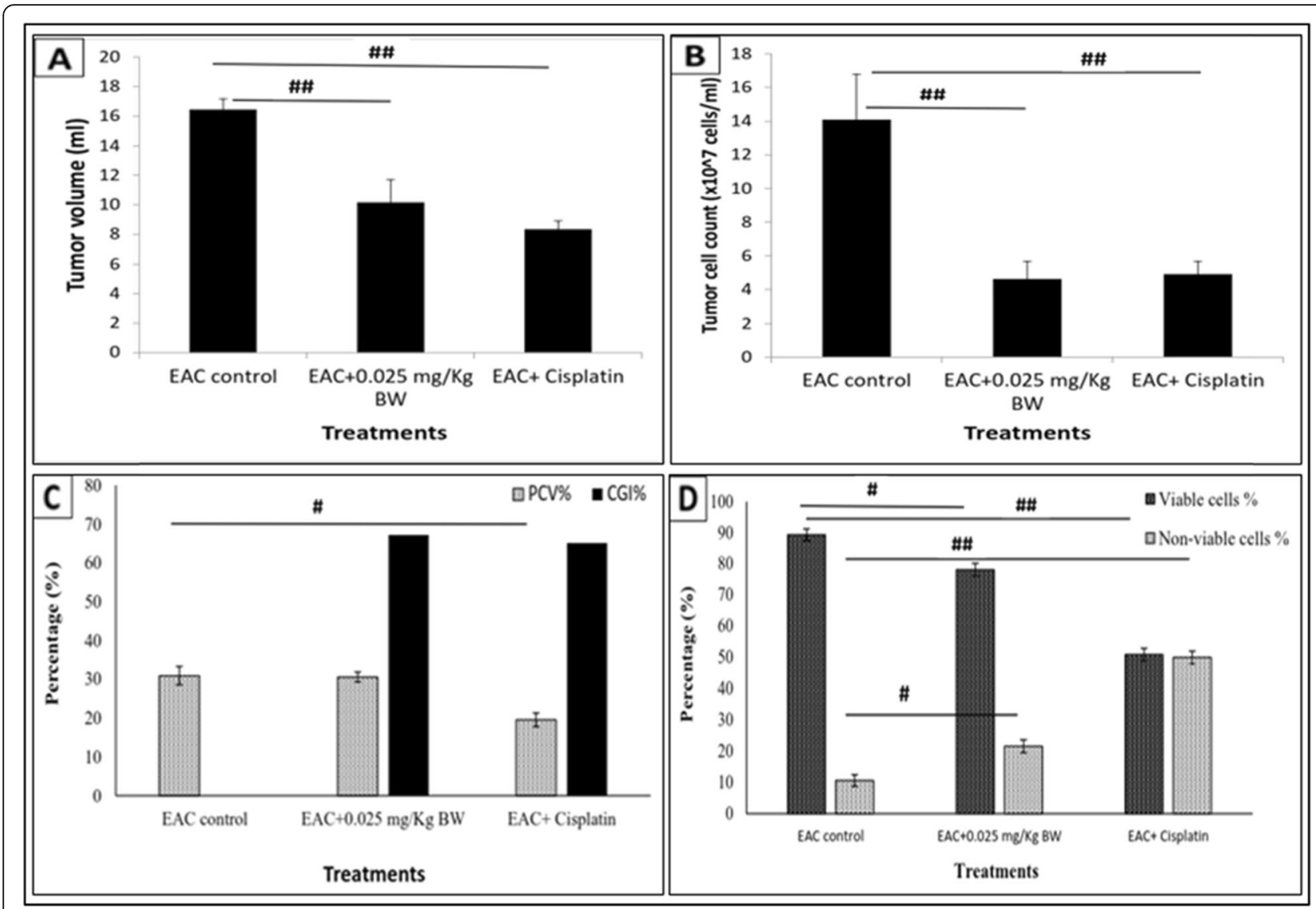

Fig. 1 Effect of A. australis venom treatment $(0.025 \mathrm{mg} / \mathrm{kg} \mathrm{BW})$ on a proliferation of ascites in EAC tumor, $\mathbf{b}$ tumor cell count, $\mathbf{c}$ percentage of packed cell volume (PCV \%) and tumor cell growth inhibition (CGl \%), and $\mathbf{d}$ percentage of viable and non-viable tumor cells. Data are expressed as mean \pm SE $(n=9)$. "Significant $(P<0.05)$, \#\# highly significant $(P<0.001)$ difference between the EAC control and treated groups using oneway ANOVA followed by the post hoc Duncan test

Cisplatin-treated EAC-bearing mice showed marked improvement as one layer of cells that resemble normal cells but with the appearance of a few scattered large cancer cells (Fig. 3d). The normal control group shows the normal architecture of the cortical tissue of the kidney that shows renal corpuscles, renal tubes, proximal convoluted tubules, distal convoluted tubules, glomerulus, and urinary space (Fig. 4a). The EAC control group shows inflammatory infiltration in the interstitial spaces, and the renal corpuscles show congestion and hypercellularity (Fig. 4b), while the renal corpuscles and tubules of venom-treated EAC-bearing mice appear like normal structure (Fig. 4c). Cisplatin-treated EAC-bearing mice show mild toxicity appearing as degeneration of tubes and congestion of corpuscles (Fig. 4d).

\section{Discussion}

Scorpion venoms are a huge variety of lipids, inorganic salts, neurotoxins, biogenic amines, peptides, proteins, and mucoproteins, which might cause biochemical and toxicological effects and may provide good templates for drug design and development (Lewis and Garcia 2003). A. australis venom is mainly involved in scorpion envenomations in North Africa and constitutes a significant public health problem in this region. It has been elaborated that scorpion venom has toxicological, pharmacological, and biochemical activities. Among these, they possess potential cytotoxic, antiproliferative, and apoptogenic effects against various cancer lines like human lung adenocarcinomas, breast, melanoma, prostate cancer, brain tumor, glioma, leukemia, and human neuroblastoma (Almaaytah and Albalas 2014).

In this study, in vitro anticancer efficacy of $A$. australis venom against a panel of human cancer cell lines was determined. In vitro results revealed that the $A$. australis venom had a selective promising activity against MCF-7 breast cancer cell line $\left(\mathrm{IC}_{50}=19.71 \mu \mathrm{g} / \mathrm{mL}\right)$. This could be due to the ability of scorpion venoms to resist cancer growth, inhibit cancer progression and metastasis, and induce apoptosis in vitro and in vivo. Several potent molecules that have been isolated from the scorpion venoms possess anticancer efficacies, ranging from 


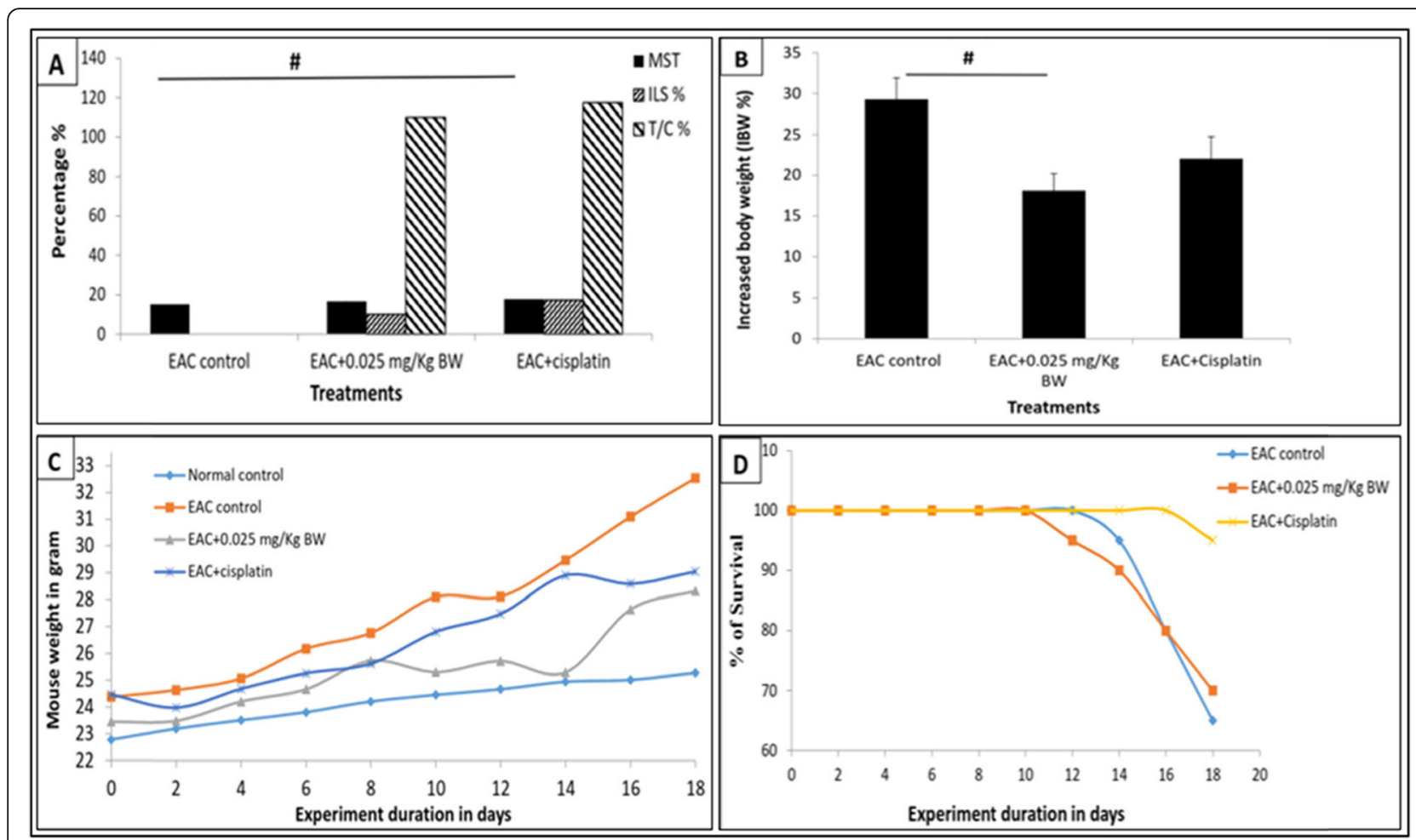

Fig. 2 Effect of A. australis venom treatment $(0.025 \mathrm{mg} / \mathrm{kg} \mathrm{BW}$ ) on a mean survival time (MST), percentage of increased life span (ILS \%), and percentage of MST ratios (T/C \%). b Percentage of increased body weight of the tumor-bearing mice. $\mathbf{c}$ Increase in body weight of untreated and treated Swiss albino female EAC-bearing mice during the experiment period from day 0 to day 18 as evaluation of tumor growth. $\mathbf{d}$ Survival curve for untreated and treated groups. Results expressed as mean \pm SE $(n=20)$. \#Significant difference between the EAC control and treated groups using one-way ANOVA followed by the post hoc Duncan test $(P<0.05)$

inhibition of proliferation and cell cycle arrest to induction of apoptosis and decreasing cell migration and invasion (Ding et al. 2014). These results matched with Zargan who reported that Androctonus crassicauda scorpion venom inhibited the growth of breast cancer cells, MCF-7 by exposure to different concentrations $(10,25$, 50,100 , and $200 \mathrm{mg} / \mathrm{mL}$ ) of the venom. The antiproliferative activity of $A$. crassicauda venom for the MCF-7 cells could be due to arresting S-phase of the cell cycle (Zargan et al. 2011).

Ascites are the nutrient tools for the survival and growth of tumor cells (Gupta et al. 2004). The in vivo results showed that $A$. australis venom exhibited a highly significant $(P \leq 0.001)$ decrease in tumor volume, tumor cell count, and viable tumor cells. The antiproliferative activity of EAC cells by the A. australis venom may be due to the reduction in body weight, tumor volume, and tumor cell counts. Therefore, the MST and ILS for the A. australis venom treatment were increased significantly in comparison with the EAC control group. Extending the life span is an essential criterion to prevent cancer and is directly associated with decreasing viable tumor cells and accumulation of ascetic fluids (Agrawal et al. 2011b).

Myelosuppression and anemia are the major problems with cancer chemotherapy. Anemia in tumor-bearing

Table 2 Effect of A. australis venom on hematological parameters of EAC-bearing mice

\begin{tabular}{llllllll}
\hline Parameter treatment & $\begin{array}{l}\text { Hemoglobin } \\
(\mathrm{g} / \mathrm{dL})\end{array}$ & $\begin{array}{l}\mathrm{RBC} \text { count } \\
\left(\times 10^{6} / \mu \mathrm{L}\right)\end{array}$ & WBC count $\left(\times 10^{3} / \mu \mathrm{L}\right)$ & $\begin{array}{l}\text { Granulocytes } \\
\left(\times 10^{3} / \mu \mathrm{L}\right)\end{array}$ & $\begin{array}{l}\text { Lymphocytes } \\
\left(\times 10^{3} / \mu \mathrm{L}\right)\end{array}$ & $\begin{array}{l}\text { Monocytes } \\
\left(\times 10^{3} / \mu \mathrm{L}\right)\end{array}$ & $\begin{array}{l}\text { Platelet count } \\
\left(\times 10^{3} / \mu \mathrm{L}\right)\end{array}$ \\
\hline Normal control & $9.72 \pm 0.15$ & $6.22 \pm 0.07$ & $5.08 \pm 0.13$ & $0.20 \pm 0.02$ & $4.64 \pm 0.23$ & $0.41 \pm 0.04$ & $248.44 \pm 11.56$ \\
EAC control & $6.18^{*} \pm 0.53$ & $4.12^{*} \pm 0.27$ & $6.27^{\#} \pm 0.69$ & $0.42^{\#} \pm 0.08$ & $5.24^{\#} \pm 0.63$ & $0.77 \pm 0.14$ & $254.89 \pm 16.33$ \\
EAC + 1/10 LD $50(0.025 \mathrm{mg} / \mathrm{kg} \mathrm{BW})$ & $8.26^{\#} \pm 0.28$ & $5.13^{\#} \pm 0.29$ & $3.57^{*} \pm 0.37$ & $0.21 \pm 0.03$ & $2.61^{*} \pm 0.30$ & $0.31 \pm 0.09$ & $536.33^{\#} \pm 23.88$ \\
EAC + cisplatin (2 mg/kg BW) & $5.98 \pm 0.56$ & $4.33 \pm 0.25$ & $5.65^{\#} \pm 0.49$ & $0.26 \pm 0.04$ & $4.63^{\#} \pm 0.42$ & $0.45 \pm 0.03$ & $599.00^{\#} \pm 30.92$ \\
\hline
\end{tabular}

Results are expressed as mean \pm SE $(n=9)$

*Significant difference between the normal control and EAC control using unpaired $t$ test $(P<0.05)$

\#Significant difference between EAC control and treated groups using one-way ANOVA followed by the post hoc Duncan test $(P<0.05)$. 
Table 3 Effect of A. australis venom on biochemical and antioxidant parameters of EAC-bearing mice

\begin{tabular}{llllllll}
\hline Parameter treatment & $\begin{array}{l}\text { Urea } \\
(\mathrm{mg} / \mathrm{dL})\end{array}$ & $\begin{array}{l}\text { Creatinine } \\
(\mathrm{mg} / \mathrm{dL})\end{array}$ & $\begin{array}{l}\text { Glucose } \\
(\mathrm{mg} / \mathrm{dL})\end{array}$ & $\begin{array}{l}\text { Cholesterol } \\
(\mathrm{mg} / \mathrm{dL})\end{array}$ & $\begin{array}{l}\text { CAT } \\
(\mathrm{U} / \mathrm{g} \text { tissue })\end{array}$ & $\begin{array}{l}\text { SOD } \\
(\mathrm{U} / \mathrm{g} \text { tissue })\end{array}$ & $\begin{array}{l}\text { GSH } \\
(\mathrm{mg} / \mathrm{g} \text { tissue })\end{array}$ \\
\hline Normal control & $29.60 \pm 1.06$ & $0.10 \pm 0$ & $141.00 \pm 2.16$ & $74.20 \pm 1.30$ & $0.8 \pm 0.03$ & $149.76 \pm 2.44$ & $0.36 \pm 0.04$ \\
EAC control & $84.90^{*} \pm 3.78$ & $0.27^{*} \pm 0.03$ & $238.67^{*} \pm 3.76$ & $81.27^{*} \pm 2.79$ & $0.74 \pm 0.02$ & $130.5 \pm 2.82$ & $0.32 \pm 0.01$ \\
EAC $+1 / 10 \mathrm{LD}_{50}(0.025 \mathrm{mg} / \mathrm{kg} \mathrm{BW})$ & $48.55^{\#} \pm 3.78$ & $0.26 \pm 0.03$ & $221.05^{\#} \pm 4.68$ & $73.82^{\#} \pm 2.12$ & $0.82 \pm 0.02$ & $165.766 \pm 4.64$ & $0.38 \pm 0.05$ \\
EAC + cisplatin $(2 \mathrm{mg} / \mathrm{Kg} \mathrm{BW})$ & $30.68^{\#} \pm 2.93$ & $0.23 \pm 0.02$ & $256.30 \pm 3.45$ & $76.58 \pm 2.97$ & $0.8 \pm 0.07$ & $473.04^{\# \# \pm 4.9}$ & $0.38 \pm 0.02$ \\
\hline
\end{tabular}

Results are expressed as mean \pm SE $(n=7)$

* Significant difference between normal control and EAC control using unpaired $t$ test $(P<0.05)$

\#Significant difference between EAC control and treated groups using one-way ANOVA followed by the post hoc Duncan test $(P<0.05)$.

mice is caused mainly by reduced RBC counts or hemoglobin levels, either because of hemolytic or myelopathic conditions (Mitsuaki et al. 1981). In the current study, hemoglobin level reduction, RBC count, was observed while the WBC count increased in the EAC control mice where $A$. australis venom treatment increased the amount of hemoglobin and maintained RBCs and WBCs normal values. The result of total differential leucocyte count revealed that granulocyte increased in EAC-bearing mice may be due to acute inflammatory reaction or pressure due to the proliferation of EAC cells (Hogland 1982). Treatment with the A. australis venom might decrease granulocytes as a result of the immunostimulating effect of scorpion venom against tumor cells. Hematological parameters are established to suggest that the venom may protect the hematopoietic system.

Hyperglycemia (increased glucose level) and increased cholesterol levels were noticed in the EAC-bearing mice compared to normal control, which agrees with Brenneman, Mathur, and Spector (1975). Treatment with $A$.
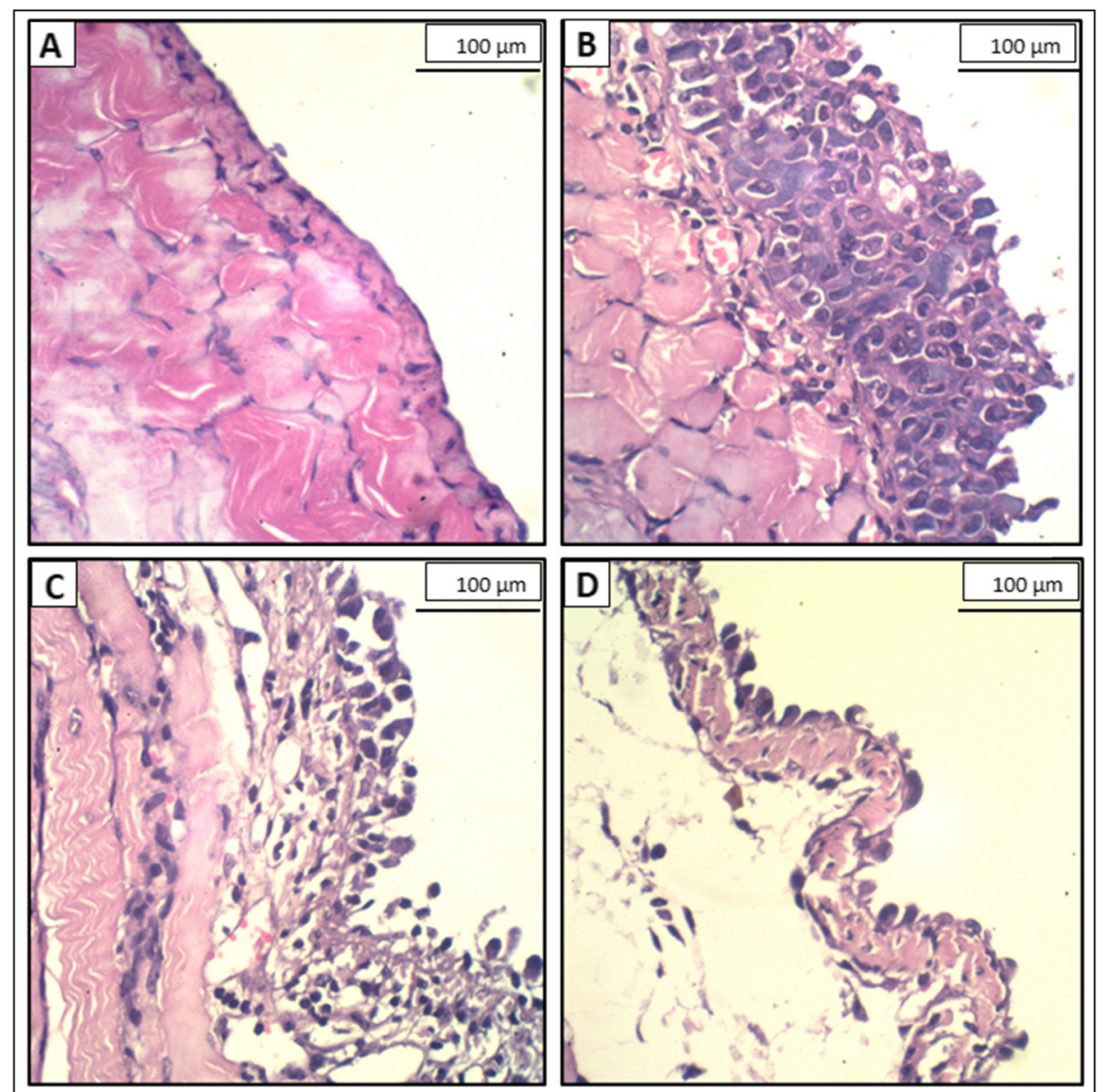

Fig. 3 Effect of A. australis venom on the peritoneal membrane of EAC bearing mice. a Normal control, b EAC control, c $0.025 \mathrm{mg} / \mathrm{kg}$ BW venomtreated EAC-bearing mice, and $\mathbf{d}$ cisplatin-treated EAC-bearing mice (H\&E scale bar, $100 \mu \mathrm{m}$ ) 


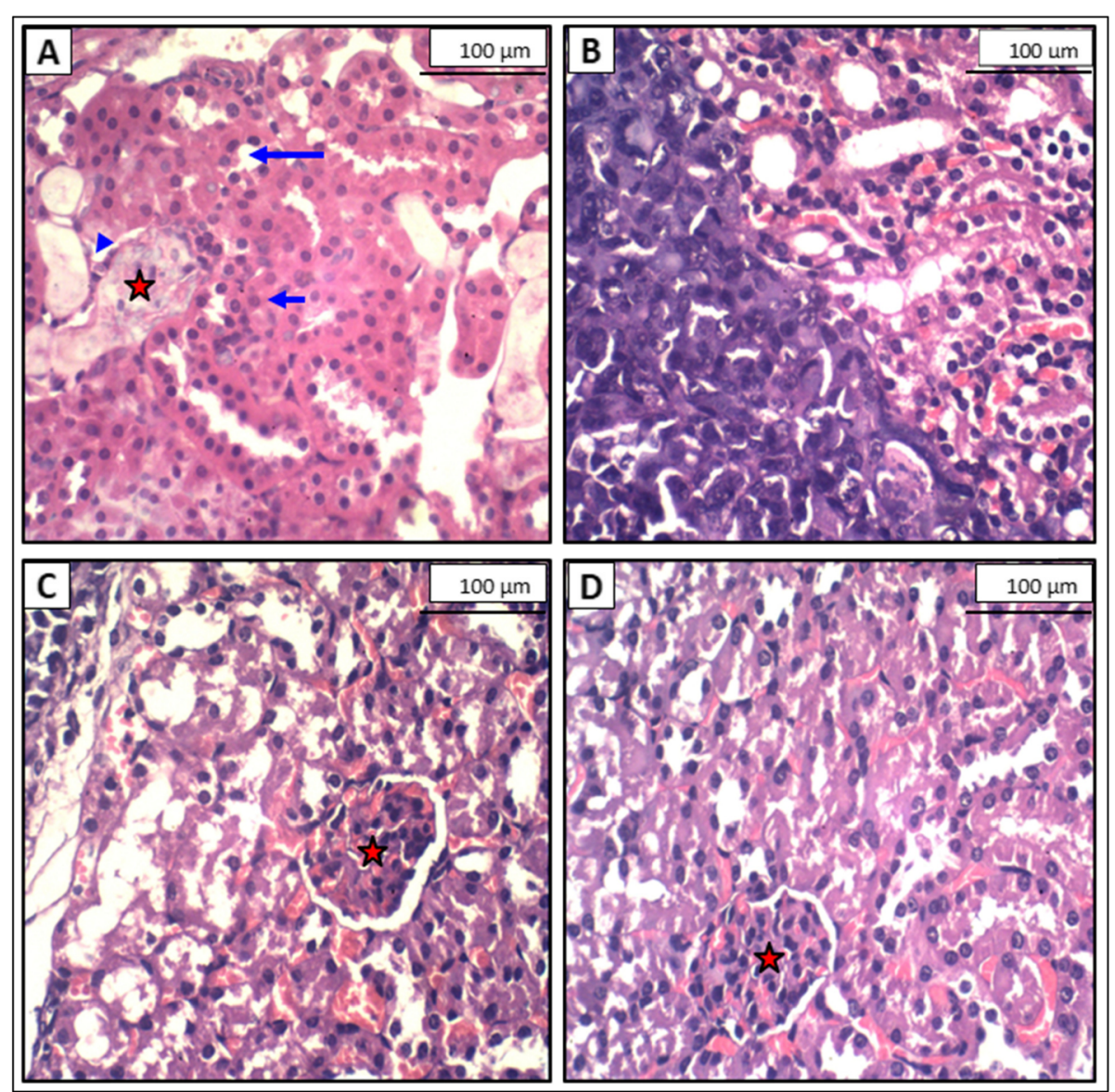

Fig. 4 Effect of A. australis venom on the kidney cortical tissue of EAC bearing mice. a Normal control, b EAC control, c $0.025 \mathrm{mg} / \mathrm{kg}$ BW venomtreated EAC-bearing mice, and $\mathbf{d}$ cisplatin-treated EAC-bearing mice. The proximal convoluted tubules (short arrows), distal convoluted tubules (long arrows), glomerulus (asterisk), and urinary space (arrowhead) are indicated (H\&E scale bar, $100 \mu \mathrm{m}$ )

australis venom tended to ameliorate these high levels. Increased urea level in EAC control compared to normal control might be attributed to the catabolic effect of the tumor and the elevation in urea production. In the meantime, increased creatinine level in the EAC control might be due to muscle necrosis (Weinberg et al. 1990). Treatment with $A$. australis venom gradually returned the increased levels of urea and creatinine to the more or less the normal values.

Antioxidant enzymes SOD and CAT are crucial enzymes in scavenging, which cleans the $\mathrm{H}_{2} \mathrm{O}_{2}$ formed during incomplete oxidation. As a whole, these antioxidant enzymes play an essential role in the body defense mechanism against the side effects of free radicals and the reactive oxygen species (ROS) in biological systems (Halliwell and Gutteridge 1999). The depletion of CAT and SOD activities as a result of tumor propagation was also reported (Marklund et al. 1982). Similar results were noticed in the present study with EAC-bearing mice. The treatment with $A$. australis venom raised the levels of SOD, CAT, and GSH in the liver homogenate of mice as compared to those of the EAC control group. So, treatment with $A$. australis venom resulted in a significant amelioration in the activities of CAT, SOD, and $\mathrm{GSH}$, and this indicates the effective antioxidant therapy and free radical scavenging function of $A$. australis venom.

Histopathological findings of the peritoneum and kidney tissues of the venom-treated EAC-bearing mice agreed with the improvement of their hematological, biochemical, and antioxidants parameters. In which, treatment with $A$. australis venom reduced the multi-layers of cancer proliferation cells and restored the normal architecture of the kidney nearly as the normal control mice.

\section{Conclusion}

In conclusion, treatment with the A. australis venom caused a promising selective cytotoxic activity against breast cancer line in vitro. Additionally, in vivo, it showed anticancer potential by causing a substantial enhancement of the antioxidant properties through elevation of antioxidant enzymes levels, resisting tumor cell 
proliferation, reducing the tumor burden, and causing prolongation of the lifespan of the tumor hosts. Further venomics studies are needed to functionally characterize the active molecules from this scorpion venom and study their mode of action on cancer cells. It can be concluded that scorpion venom offers a safe treatment of cancer having less toxicity than traditional chemotherapy.

\section{Abbreviations}

A. australis: Androctonus australis; EAC: Ehrlich ascites carcinoma;

I.P.: Intraperitoneal injection; PCV: Packed cell volume; CGl: Cell growth inhibition; IBW: Increased body weight; MST: Mean survival time; T/C: MST ratio (treated/control); ILS: Increased life span; CBC: Cell blood count (Hb, hemoglobin; RBCs, red blood cells; WBCs, white blood cells); CAT: Catalase; GSH: Glutathione; MDA: Malondialdehyde; ROS: Reactive oxygen species; $I_{50}$ : Half maximal concentration; HCT116: Colon cancer; HepG2: Liver cancer; MCF-7: Breast Michigan Cancer Foundation-7; PC-3: Prostate cancer; WISH: Normal human amniotic epithelial cells

\section{Acknowledgements}

The first author owe to Mohamed A. Abdel-Rahman for his continuous help and advice from the initiative idea to manuscript launch

\section{Authors' contributions}

MAAR initiated the idea of the manuscript, while MSN carried out and wrote the included work under the supervision of MMAD, ZN, and IAIA, while MAT helped in the analysis and writing of the in vitro results. All authors contributed in the revision and analysis of fata and read and approved the final manuscript

\section{Funding}

No funding

\section{Availability of data and materials}

Data will not be shared, only by request from corresponding author.

\section{Ethics approval and consent to participate}

All procedures related to care and maintenance of the animals were performed according to the international guiding principles for animal research and approved by the Suez Canal University bioethics and animal ethics committee (the approval no. 201505)

\section{Consent for publication}

Not applicable

\section{Competing interests}

The authors declare that they have no competing interest.

\section{Author details}

Chemistry Department, Faculty of Science, Suez Canal University, Ismailia 41522, Egypt. ${ }^{2}$ Pharmacology Department, Faculty of Veterinary Medicine, Suez Canal University, Ismailia 41522, Egypt. ${ }^{3}$ Zoology Department, Faculty of Science, Suez Canal University, Ismailia 41522, Egypt. ${ }^{4}$ Hormones Department, Medical Research Division, National Research Centre, Dokki, Cairo, Egypt.

\section{Received: 7 November 2019 Accepted: 2 March 2020}

\section{Published online: 10 March 2020}

\section{References}

Abdel-Rahman, M. A., Harrison, P. L., \& Strong, P. N. (2015). Snapshots of scorpion venomics. Journal of Arid Environments, Special issue on Toxins in Desert Environments, 112, 170-176.

Abdel-Rahman, M. A., Quintero-Hernandez, V., \& Possani, L. D. (2013). Venom proteomic and venomous glands transcriptomic analysis of the Egyptian scorpion Scorpio maurus palmatus (Arachnida: Scorpionidae). Toxicon, 74, 193-207.

Aebi H. 1984. [13] Catalase in vitro. Pp. 121-126 in Methods in Enzymology, Oxygen Radicals in Biological Systems. Academic Press.
Agrawal, S. S., Saraswati, S., Mathur, R., \& Pandey, M. (2011a). Antitumor properties of Boswellic acid against Ehrlich ascites cells bearing mouse. Food and Chemical Toxicology, 49, 1924-1934.

Agrawal, S. S., Saraswati, S., Mathur, R., \& Pandey, M. (2011b). Cytotoxic and antitumor effects of brucine on Ehrlich ascites tumor and human cancer cell line. Life Science, 89, 147-158.

Al-Asmari, A. K., Riyasdeen, A., \& Islam, M. (2018). Scorpion venom causes apoptosis by increasing reactive oxygen species and cell cycle arrest in MDAMB-231 and HCT-8 cancer cell lines. Journal of Evidence-Based Integrative Medicine, 23, 215658721775179.

Almaaytah, A., \& Albalas, Q. (2014). Scorpion venom peptides with no disulfide bridges: a review. Peptides, 51, 35-45.

Badr M.O.T., N.M.M. Edrees, A.A.M. Abdallah, M.A. Hashem, N.A.M.N. El-Deen, A.N.F. Neamat-Allah, and H.T.H. Ismail. 2011. Propolis protects against methotrexate induced hepatorenal dysfunctions during treatment of Ehrlich carcinoma 7: 313-319.

Banchroft J.D. and A. Stevens. 1996. Theory and practice of histological techniques (Fourth Ed.). Churchil Livingstone, New York, London, San Francisco, Tokyo.

Béchohra, L., Laraba-Djebari, F., \& Hammoudi-Triki, D. (2016). Cytotoxic activity of Androctonus australis hector venom and its toxic fractions on human lung cancer cell line. Journal of Venomous Animals and Toxins including Tropical Diseases, 22.

Beutler, E., Duron, O., \& Kelly, B. M. (1963). Improved method for the determination of blood glutathione. The Journal of laboratory and clinical medicine, 61, 882-888.

Bhatnagar, P., Pant, A. B., Shukla, Y., Panda, A., \& Gupta, K. C. (2016). Hyaluronic acid grafted PLGA copolymer nanoparticles enhance the targeted delivery of Bromelain in Ehrlich's ascites carcinoma. European Journal of Pharmaceutics and Biopharmaceutics, 105, 176-192.

Bray, F., Ferlay, J., Soerjomataram, I., Siegel, R. L., Torre, L. A., \& Jemal, A. (2018). Global cancer statistics 2018: GLOBOCAN estimates of incidence and mortality worldwide for 36 cancers in 185 countries. CA: A Cancer Journal for Clinicians, 68, 394-424.

Brenneman, D. E., Mathur, S. N., \& Spector, A. A. (1975). Characterization of the hyperlipidemia in mice bearing the Ehrlich ascites tumor. European journal of cancer, 11, 225-230.

BW S. and W CP (2014). World Cancer Report, 2014.

Coulombe, J. J., \& Favreau, L. (1963). A new simple semimicro method for colorimetric determination of urea. Clinical Chemistry, 9, 102-108.

Ding J., P J. Chua, B H Bay, and P Gopalakrishnakone. 2014. Scorpion venoms as a potential source of novel cancer therapeutic compounds. Experimental biology and medicine (Maywood, NJ) 239:387-393.

Ejaz, S., Hashmi, F. B., Malik, W. N., Ashraf, M., Nasim, F. U.-H., \& Iqbal, M. (2018). Applications of venom proteins as potential anticancer agents. Protein Pept Lett, 25, 688-701.

El-Azab, M., Hishe, H., Moustafa, Y., \& El-Awady, E.-S. (2011). Anti-angiogenic effect of resveratrol or curcumin in Ehrlich ascites carcinoma-bearing mice. European Journal of Pharmacology, 652, 7-14.

Ferlay, J., Soerjomataram, I., Dikshit, R., Eser, S., Mathers, C., Rebelo, M., et al. (2015). Cancer incidence and mortality worldwide: sources, methods and major patterns in GLOBOCAN 2012. Int I Cancer, 136, E359-E386.

Ghosh, A., Roy, R., Nandi, M., \& Mukhopadhyay, A. (2019). Scorpion venom-toxins that aid in drug development: a review. Int J Pept Res Ther, 25, 27-37.

Gupta, M. Mazumder, U. K. Kumar, R. S., Sivakumar, T., \& Vamsi, M. L. M. (2004). Antitumor activity and antioxidant status of Caesalpinia bonducella against Ehrlich ascites carcinoma in Swiss albino mice. Journal of Pharmacological Sciences, 94, 177-184.

Halliwell B. and J M Gutteridge. 1999. Free Radicals in Biology and Medicine (3rd eds.). Oxford University Press, Oxford.

Harrison, P. L., Abdel-Rahman, M. A., Strong, P. N., Tawfik, M. M., \& Miller, K. (2016). Characterisation of three alpha-helical antimicrobial peptides from the venom of Scorpio maurus palmatus. Toxicon, 117, 30-36.

Heinen, T. E., \& Gorini da Veiga, A. B. (2011). Arthropod venoms and cancer. Toxicon, 57, 497-511.

Hogland, H. C. (1982). Hematological complications of cancer chemotherapy. Seminars in Oncology, 9, 95-102

Larsen, K. (1972). Creatinine assay in the presence of protein with LKB 8600 Reaction Rate Analyser. Clinica Chimica Acta, 38, 475-476.

Lazarus, H., Tegeler, W., Mazzone, H., Leroy, J., Boone, B., \& Foley, G. (1966). Determination of sensitivity of individual biopsy specimens to potential 
inhibitory agents: evaluation of some explant culture methods as assay systems. Cancer Chemotherapy Reports, 50, 543-555.

Lewis, J. R., \& Garcia, L. M. (2003). Therapeutic potential of venom peptides. Drug Discovery, 2, 790-802

Marklund, S. L., Westman, N. G., Lundgren, E., \& Roos, G. (1982). Copper and zinc containing superoxide dismu-tase, manganese-containing superoxide dismutase, catalase, and glutathione peroxidase in normal and neoplastic human cell lines and normal human tissues. Cancer Research, 42, 1955-1961.

Mitsuaki, M., Ikuo, N., Masako, H., Yutaka, T., \& Kunio, Y. (1981). Lipid peroxide levels and lipid content of serum lipoprotein fractions of pregnant subjects with or without pre-eclampsia. Clinica Chimica Acta, 115, 155-161.

Nafie M.S., M.M.A. Daim, M.A. Abdel-Rahman, and Z.I. Nabil. 2014. Proteomic and biochemical characterization of the Egyptian scorpion Androctonus australis venom. Egyptian Journal of Natural Toxins $11(1,2): 30-51$.

Nie N.H., D.H. Bent, and C.H. Hull. 1975. SPSS: Statistical package for the social sciences (Vol. 421). McGraw-Hill New York.

Nishikimi, M., Appaji, N., \& Yagi, K. (1972). The occurrence of superoxide anion in the reaction of reduced phenazine methosulfate and molecular oxygen. Biochemical and biophysical research communications, 46, 849-854.

Ortiz, E., Gurrola, G. B., Schwartz, E. F., \& Possani, L. D. (2015). Scorpion venom components as potential candidates for drug development. Toxicon, 93, 125-135.

Pandya, N. B., Tigari, P., Dupadahalli, K., Kamurthy, H., \& Nadendla, R. R. (2013). Antitumor and antioxidant status of Terminalia catappa against Ehrlich ascites carcinoma in Swiss albino mice. Indian Journal of Pharmacology, 45, 464-469.

Richmond, W. (1973). Preparation and properties of a cholesterol oxidase from Nocardia sp. and its application to the enzymatic assay of total cholesterol in serum. Clinical Chemistry, 19, 1350-1356.

Salem, M. L., Shoukry, N. M., Teleb, W. K., Abdel-Daim, M. M., \& Abdel-Rahman, M. A. (2016). In vitro and in vivo antitumor effects of the Egyptian scorpion Androctonus amoreuxi venom in an Ehrlich ascites tumor model. SpringerPlus, 5, 570.

Sarfo-Poku, C., Eshun, O., \& Lee, K. H. (2016). Medical application of scorpion venom to breast cancer: A mini-review. Toxicon, 122, 109-112.

Skehan, P., Storeng, R., Scudiero, D., Monks, A., McMahon, J., Vistica, D., et al. (1990). New colorimetric cytotoxicity assay for anticancer-drug screening Journal of the National Cancer Institute, 82, 1107-1112.

Sur, P., \& Ganguly, D. K. (1994). Tea plant root extract (TRE) as an antineoplastic agent. Planta Medica, 60, 106-109

Triner, L., Vulliemoz, Y., Schwartz, I., \& Nahas, G. (1970). Cyclic phosphodiesterase activity and the action of papaverine. Biochemical and biophysical research communications, 40, 64-69.

Weinberg, J. M., Davis, J. A., Abarzua, M., Kiani, T., \& Kunkel, R. (1990). Protection by glycine of proximal tubules from injury due to inhibitors of mitochondrial ATP production. American Journal, 258, 1127-1140.

Zargan, J., Sajad, M., Umar, S., Naime, M., Ali, S., \& Khan, H. A. (2011). Scorpion (Androctonus crassicauda) venom limits growth of transformed cells (SHSY5Y and MCF-7) by cytotoxicity and cell cycle arrest. Experimental and Molecular Pathology, 91, 447-454.

\section{Publisher's Note}

Springer Nature remains neutral with regard to jurisdictional claims in published maps and institutional affiliations.

\section{Submit your manuscript to a SpringerOpen ${ }^{\circ}$ journal and benefit from:}

- Convenient online submission

- Rigorous peer review

- Open access: articles freely available online

- High visibility within the field

- Retaining the copyright to your article

Submit your next manuscript at $\boldsymbol{\nabla}$ springeropen.com 